\title{
ENTREPRENEURSHIP BY ALLIANCE
}

\section{Barbara KRUg and JUdith MetHa}

\begin{tabular}{|l|l|}
\hline \multicolumn{2}{|l|}{ ERIM REPORT SERIES RESEARCH IN MANAGEMENT } \\
\hline ERIM Report Series reference number & ERS-2001-85-ORG \\
\hline Publication & December 2001 \\
\hline Number of pages & 39 \\
\hline Email address corresponding author & bkrug@fbk.eur.nl \\
\hline Address & Erasmus Research Institute of Management (ERIM) \\
& Rotterdam School of Management / Faculteit Bedrijfskunde \\
& Erasmus Universiteit Rotterdam \\
& P.O.Box 1738 \\
& 3000 DR Rotterdam, The Netherlands \\
& Phone: +31 10 408 1182 \\
& Fax: $\quad+31104089640$ \\
& Email: info@erim.eur.nl \\
& Internet: $\quad$ www.erim.eur.nl \\
\hline
\end{tabular}

Bibliographic data and classifications of all the ERIM reports are also available on the ERIM website: www.erim.eur.nl 


\title{
ERASMUS RESEARCH INSTITUTE OF MANAGEMENT
}

\author{
REPORT SERIES
}

RESEARCH IN MANAGEMENT

\begin{tabular}{|c|c|c|}
\hline \multicolumn{3}{|c|}{ BIBLIOGRAPHIC DATA AND CLASSIFICATIONS } \\
\hline Abstract & \multicolumn{2}{|c|}{$\begin{array}{l}\text { Recent years have seen the introduction of markets and a system of private property rights in } \\
\text { China with a view to changing the composition of production and demand and enhancing } \\
\text { welfare. Central to the success of these reforms is the rise of entrepreneurship with its potential } \\
\text { to set the economy on a higher growth path by supplying the products which consumers need } \\
\text { and want, creating new employment opportunities, and introducing new and more efficient } \\
\text { technologies of production. But to what extent can we expect to see entrepreneurs in China } \\
\text { behaving like their counterparts in the advanced industrial economies of Western Europe, } \\
\text { Japan, and the United States? This is the question we address in this chapter. In our view, the } \\
\text { reform programme has, indeed, opened up new opportunities for private enterprise activity; but } \\
\text { idiosyncrasies of the business environment are at the same time generating novel institutional } \\
\text { arrangements in support of entrepreneurs' investments. We agree, therefore, with Herrick and } \\
\text { Kindleberger when they assert that "Development ought not to be viewed as a monotonic, } \\
\text { stylized path, ever onward and upward, historically established and invariably repeated" (1983, } \\
\text { p.62). }\end{array}$} \\
\hline \multirow{3}{*}{$\begin{array}{l}\text { Library of Congress } \\
\text { Classification } \\
(\mathrm{LCC})\end{array}$} & $5001-6182$ & Business \\
\hline & $\begin{array}{l}5546-5548.6 \\
5548.7-5548.85\end{array}$ & $\begin{array}{l}\text { Office Organization and Management } \\
\text { Industrial Psychology }\end{array}$ \\
\hline & HD 85.CHINA & Economic Growth, Development, Planning \\
\hline \multirow{3}{*}{$\begin{array}{l}\text { Journal of Economic } \\
\text { Literature } \\
\text { (JEL) }\end{array}$} & $\mathrm{M}$ & Business Administration and Business Economics \\
\hline & & $\begin{array}{l}\text { Business Administration: general } \\
\text { Firm Objectives, Organization and Behaviour }\end{array}$ \\
\hline & $\mathrm{P} 21$ & Socialist Systems and Transitional Economies \\
\hline \multirow{3}{*}{$\begin{array}{l}\text { European Business Schools } \\
\text { Library Group } \\
\text { (EBSLG) }\end{array}$} & $85 \mathrm{~A}$ & Business General \\
\hline & $\begin{array}{l}100 B \\
240 B\end{array}$ & $\begin{array}{l}\text { Organization Theory (general) } \\
\text { Information Systems Management }\end{array}$ \\
\hline & $170 \mathrm{~F}$ & Economic policy \\
\hline \multicolumn{3}{|c|}{ Gemeenschappelijke Onderwerpsontsluiting (GOO) } \\
\hline \multirow[t]{3}{*}{ Classification GOO } & 85.00 & Bedrijfskunde, Organisatiekunde: algemeen \\
\hline & $\begin{array}{l}85.05 \\
85.08\end{array}$ & $\begin{array}{l}\text { Management organisatie: algemeen } \\
\text { Organisatiesociologie, organisatiepsychologie }\end{array}$ \\
\hline & 83.25 & Economische transitie \\
\hline \multirow[t]{3}{*}{ Keywords GOO } & \multicolumn{2}{|c|}{ Bedrijfskunde / Bedrijfseconomie } \\
\hline & \multicolumn{2}{|c|}{ Organisatieleer, informatietechnologie, prestatiebeoordeling } \\
\hline & \multicolumn{2}{|c|}{$\begin{array}{l}\text { Economische ontwikkeling, Economische hervormingen, China, Westerse Wereld, Overheid, } \\
\text { Institutionele Economie, Ondernemerschap, Bedrijfsplanning, Economische samenwerking }\end{array}$} \\
\hline Free keywords & \multicolumn{2}{|c|}{$\begin{array}{l}\text { Economic development, Economic Growth, Transition, China, Western Economies, } \\
\text { Government, Institutional Economy, Entrepreneurship, Business Planning, Business } \\
\text { Networking }\end{array}$} \\
\hline
\end{tabular}




\section{ENTREPRENEURSHIP BY ALLIANCE}

\section{Barbara Krug and Judith Mehta}

This version: November 22nd 2001.

Word count: 9086 


\subsection{INTRODUCTION}

Recent years have seen the introduction of markets and a system of private property rights in China with a view to changing the composition of production and demand and enhancing welfare. Central to the success of these reforms is the rise of entrepreneurship with its potential to set the economy on a higher growth path by supplying the products which consumers need and want, creating new employment opportunities, and introducing new and more efficient technologies of production. But to what extent can we expect to see entrepreneurs in China behaving like their counterparts in the advanced industrial economies of Western Europe, Japan, and the United States? This is the question we address in this chapter. In our view, the reform programme has, indeed, opened up new opportunities for private enterprise activity; but idiosyncrasies of the business environment are at the same time generating novel institutional arrangements in support of entrepreneurs' investments. We agree, therefore, with Herrick and Kindleberger when they assert that "Development ought not to be viewed as a monotonic, stylized path, ever onward and upward, historically established and invariably repeated" (1983, p.62).

In this chapter, we analyse modes of entrepreneurship in one particular province, Shanxi, which lies to the north-east of Beijing. We claim that six idiosyncratic features of the business environment generate a particularly high level of economic and institutional uncertainty for would-be entrepreneurs in this province; these are:

- a dual economy

- missing and poorly functioning markets

- poorly developed institutional arrangements 
- incomplete private property rights

- a weak regulatory regime

- and the 'newness' of private enterprise.

We suggest that the high transaction costs associated with uncertainty, together with resource constraints, are responsible for pushing entrepreneurs into alliances with others. This is because alliances raise the probability of success and the expected level of profits in the new private sector. Under these conditions, the establishment of a firm and its expansion path turn on the ability of the entrepreneur to identify, and form alliances with, the 'right' kind of others.

Our account is supported by 27 case studies of entrepreneurs acquired through fieldwork in Shanxi Province in 1999. The age and principal productive activities of respondents are described in Table 1 (in the Appendices). Shanxi Province was selected for fieldwork because it has an extremely fast-growing private sector but has not been a major recipient of foreign direct investment or preferential treatment by the State. Growth has therefore been endogenous. Interviews were semistructured and lasted for at least two hours (and sometimes much longer) with the aim of capturing qualitative data ${ }^{1}$. It cannot be claimed that the sample of respondents is representative by the usual social-scientific standards of Western research practice since we were dependent for access to entrepreneurs on three mediating agencies: the principal commercial bank of the region, a university in the provincial capital, and local Party officials; each of these agencies is likely to have applied their own filters to the sample. The alternative would have been to wait for the time it takes for Western sampling methods to be acceptable and practicable. 
Nonetheless, we suggest the resulting dataset is rich in information and offers a unique glimpse of key features of entrepreneurship in Shanxi Province at this stage of the reform programme.

The chapter is organised as follows. Section 2 describes the particular features of uncertainty which characterise the business environment and which generate high transaction costs for would-be entrepreneurs. Section 3 describes the impact of uncertainty on profit, investment and product mix. Section 4 develops the claim that high transaction costs, together with resource constraints, push entrepreneurs into alliances with others. And Section 5 concludes with a discussion of some of the ramifications of our findings. To add substance to our claims, the Appendices contain short case studies of four representative entrepreneurs.

\subsection{THE BUSINESS ENVIRONMENT.}

The economic, social and political environment facing a potential entrepreneur in the newly reformed China has distinct transaction cost-generating features. These features need to be regarded as inter-related but, for expositional purposes, they can be described under the following six headings.

\subsection{The dual economy}

China is characterised by the co-existence of a socialist sector where economic activity continues in large part to be coordinated by centrally-planned quotas and low state-controlled prices, and a competitive, free-enterprise sector where activity is coordinated by the price mechanism with (relatively) free entry to private 
entrepreneurs. Producers would face far less uncertainty if just one sector predominated, and if that sector manifested some stability. As it is, both the socialist sector and the free-enterprise sector are in a state of flux. Negotiating the divide between sectors is a primary source of transaction costs since time and money must be spent cultivating access to, and good relations with, those bureaucrats and Party officials in the state sector who have control over key resources. But success has high rewards: an individual who succeeds in buying inputs at low state prices while selling their own goods in competitive markets can appropriate the profits accruing to arbitrage (Nee \& Matthews, 1996; Nee \& Su, 1990; Nee, 2000).

\subsection{Missing and poorly functioning markets}

The emerging market situation in China is characterised at best by poorly functioning markets, and at worst by missing markets, for capital funds, other factor inputs, risk management, and information of all kinds (Stigler, 1989; Boisot, 1995). This situation necessarily adds to the costs of undertaking transactions.

Commercial banks, for example, simply do not have sufficient capital available to meet the needs of all budding and actual entrepreneurs, nor are they practised in assessing the risks and managing the insurance associated with all the novel ventures presented to them. Banks are not the only source of capital; but locating other sources is difficult for would-be entrepreneurs. Information relating to the availability, price and location of other inputs to production (for example, appropriately skilled labour and intermediate goods) is similarly either lacking 
altogether or disaggregated. All of the 27 entrepreneurs whom we interviewed spoke of the inadequacy of the services provided by commercial banks, and/or described access to capital, appropriately skilled labour, and information as key problem areas $^{2}$.

However, on the positive side, the newly unleashed desire for consumption in China means that an individual can earn high profits if they can acquire access to factor inputs and can identify ways of establishing business relations across markets and provinces. A budding entrepreneur, then, faces high deterrents to market entry but, also, robust incentives to succeed.

\subsection{Poorly developed institutional arrangements}

China is short of the kind of public and private sector agencies which are found in plentiful supply in a mature industrial economy and which support the coordination of market activity; these include employment agencies, law and accountancy firms, commercial banks, insurance agencies, and chambers of commerce. Islam and Chowdhury (1997), for example, report that there are only 75,000 lawyers and 6,000 law firms across China. In economies with a long experience of private sector production, these agencies act as repositories of information and expertise, and as intermediaries in the negotiations between potential business partners. But where they exist in China, the experience of personnel, and the information and other resources available to them, are severely limited. 
The demand for intermediaries is high; as one of our respondents pointed out, China has an inadequate capital base and intermediaries are needed to locate sources of capital and to broker agreements. New agencies are, indeed, evolving and they resemble their counterparts in the West in terms of their structure and organisation, and the services they seek to supply. And, certainly, through their activities a range of quasi- institutional business arrangements has been engendered, such as $>$ laws $=$ and $>$ legal $=$ precedents, accountancy procedures, capital markets, and guidelines for business practice. As such, the new agencies would appear to contribute to a reduction of the transaction costs associated with the management of risk, the acquisition of capital funds, the enforcement of contracts, and the dissemination of information. However, they are inadequate to the task of lubricating the wheels of private enterprise. Since the arrangements engendered by the new agencies do not emanate from the State at its centre, their status is undetermined and at best equivocal, particularly where transactors seek to cross provincial boundaries. And since the experience of personnel is limited, and the coverage of exchange relations is incomplete, the capacity of the new agencies to broker and subsequently to enforce the wide range of novel transactions is commonly recognised by entrepreneurs to lack substance.

\subsection{Incomplete private property rights}

In the period $1980-84$, legislation was introduced to establish private property rights as a way of supporting private enterprise activity. For the first time in recent history, individuals and enterprises of various kinds now find they can have lawful private ownership of both physical and financial assets. Under the legislation, the State 
>guarantees $=$ that asset holders can exclude others from use of the same asset. In the Western legal sense, this guarantee does not constitute a complete private property right, but a >possessory= right (Furubotn \& Pejovich, 1974; Posner, 1980; Fukuyama, 1995), which is legally binding only when resources are used within the politically defined market sector and where effective law enforcement agencies exist $^{3}$. Despite these limitations, the legislation has had the desired effect on investment by raising the expectations of individuals that they can appropriate the returns to their ventures.

The impetus to invest is evident both in urban areas where the state manufacturing sector is concentrated and in the countryside. In the case of the former, a variety of state agencies are taking advantage of their new-found entitlement to become the lawful owners of physical and financial assets. In the case of the latter, the village has been established as the $>$ natural owner= of all assets within village boundaries, with the further assignment of private property rights to individuals taking place contingent on negotiations within the village or its next superior administrative unit (Rozelle \& Li, 1998). Three procedures have come to dominate the transfer of assets into private hands.

First, control over resources and possession is commonly recognised as the first step towards the acquisition of private property rights. This procedure can be thought of as one of $>$ cold privatisation=; it is the means by which state cadres previously in 
control of resources are able to transform themselves into the managers, if not the owners, of those resources. The second procedure is to acknowledge past investment into a resource. Thus, land which hitherto was farmed by a group of households under the People=s Commune System is apportioned and assigned to private households within that original group. However, at its best, this second procedure secures sharecropping and similar lease contracts while full, legallyenforceable private property rights are still missing. From the early 1990s, a third procedure has emerged. Those entrepreneurs seeking to acquire land without some original association with it, have been permitted to purchase a lease, if local politicians and Party cadres are pliant and sanction the use to which the land will be put. However, security of tenure beyond the period specified in the lease, the right to change of use, and the right to transfer ownership, remain uncertain.

It is true to say, then, that opportunities for private enterprise activity have, indeed, expanded with the introduction of private property rights. But procedures for the assignment of rights to individuals mean that bureaucrats, Party cadres, and other local politicians continue as a force to be reckoned with in determining who can do what with land which is in private hands (Oi, 1996; Unger, 1995).

\subsection{A weak regulatory regime}

The reform process in China has been characterised by on-going shifts in the regulatory regime across a number of dimensions. 
While regulations are negotiated and agreed in the first instance at the centre in Beijing, China is de facto a decentralised (that is, federalist) state in that each locality enjoys the leeway to modify, manipulate - and even create - its own regulatory regime. As a consequence, entrepreneurs do not face a unified system of taxes, laws and regulations but a variety of systems which differ from province to province and, sometimes, even from county to county within a single province. The heterogeneity of systems, and their lack of stability, adds to the uncertainties associated with production and exchange, particularly where entrepreneurs seek to transact across provinces. At the same time, within a locality, the regulatory regime is experienced as a $>$ soft= and eminently malleable constraint on economic activity, with the tax base, the tax rate, and the application of regulations open to negotiation - at least, to those with influence. As Oi (ibid) observes: ALocal officials routinely manipulate regulations to allow local enterprises to receive the maximum tax advantages and exemptions. This keeps more revenue within the locality and adds to the competitive advantage of the enterprises, which also means that of the locality. ... [the county tax bureau] may also use its connections to influence other agencies, such as banks, to bend the rules in favour of a particular enterprise.؟ (P.184).

Despite encouragement of private enterprise from the State at its centre, and despite advances in the assignment of private property rights, economic activity continues to take place under considerable risk of confiscation as a result of opportunism and/or where private enterprise is frowned upon by the local political leadership. In the early days of the reform programme, confiscation involved the seizure of physical assets 
or bank accounts from private firms or households; more recently, it can take the form of ad hoc taxation once net profits are known, and can involve the sudden appearance of Party cadres on the doorstep asking for a share of the returns (Krug, 1997; Gambetta, 1993; Boisot \& Child, 1988). During fieldwork, respondents provided enough anecdotal evidence to suggest that ad hoc systems of taxation, or >invitations $=$ to contribute to local community facilities, are a real threat.

The risk of confiscation of assets, together with the malleability of the regulatory regime, has implications, not only for the conduct and performance of private enterprise once it is up and running, but at the planning stage when the decision is taken about whether or not to proceed with a business venture. Arguably one of the most dramatic differences between the business environments to be found in China and in the mature economies of the West is that the expected returns to an investment cannot be calculated solely by reference to economic parameters: the political climate, and the control of local politicians over the regulatory regime, both have to be taken into account. As one of our respondents remarked, AEverything depends on the government气.

\subsection{The >newness $=$ of private enterprise}

Private enterprise activity is still relatively novel in China and so the very newness of the private firm as an organisational form generates a high level of uncertainty for would-be entrepreneurs (Krug \& Polos, 2000). There are several dimensions to this kind of uncertainty. 
First, budding entrepreneurs are endowed with a low level of expertise with regard to the organisation of production and the management of the private firm. However enthusiastic the current generation is to embrace private enterprise, the formal education they received did not equip them with the expertise and acumen which might be thought necessary for sound business practice in a market environment. There is little awareness of the mechanics of demand and supply, and price- and income elasticities, even at an intuitive level, and there is no systematic knowledge base which could help entrepreneurs to identify, and subsequently to quantify, the risks associated with their ventures. Second, the newness of the private sector means business practices are heterogeneous. Thus, there is no obvious model of best practice to imitate and there are no standardised routines of business practice which entrepreneurs can rely on for the smooth passage of transactions. And, finally, in the absence of a history of experience of business strategy, there is no collective memory about what can go wrong and how to resolve problems when they arise.

2.7 Institutional uncertainty Chinese entrepreneurs have robust incentives to succeed in their private sector business activities. There is growing domestic demand for final and intermediate goods, a low level of competition from indigenous suppliers in most markets, and (as yet) relatively poor penetration of markets by foreign firms. Yet the six features of the economy we have described in this section all point to a high level of institutional uncertainty. We use this term in order to emphasize two facets of the business environment which potentially constrain entrepreneurial activity. First, weak institutions are unable to reduce uncertainty in the business environment to the level 
experienced by entrepreneurs in a more mature market economy. And, second, the very co-existence of a multiplicity of different institutional forms and practices, many of which are in flux, is a source of uncertainty itself.

Under these conditions, the transaction costs accompanying production and exchange relations are high, and mistakes are expensive. In particular, customer and supplier firms, employees, and other business partners cannot be expected to act according to well-established and, hence, predictable patterns of behaviour, as they might in a more mature and stable environment. The rational entrepreneur can therefore expect instead to elicit a large variance in the responses of economic agents to his or her actions, and a large variance in the responses of business partners to external shocks (Stinchcombe, 1965). Moreover, while the potential exists for costly principal-agent problems (that is, the problems of adverse selection and moral hazard), it is not within an entrepreneur=s power to enforce a specific kind of behaviour since social and legal mechanisms of enforcement are unstable, can change rapidly over time, and are likely to vary from one locality to another. What do these factors imply for the practice of entrepreneurship?

\subsection{THE IMPACT OF UNCERTAINTY ON PROFIT, PRODUCT MIX AND INVESTMENT.}

Fieldwork reveals that entrepreneurs are keen to ensure their investments will generate a steady stream of profits over time. This objective translates into the pursuit of long-term business relations in factor and product markets in order to 
minimise the risks of opportunism and to transcend the mere 'wheeling and dealing' of spot markets ${ }^{4}$. In these respects, the aspirations of entrepreneurs in China are similar to those of their counterparts elsewhere (Sako, 1992; Lyons \& Mehta, 1997). But as we have already observed, it is particularly difficult in China to assess the level of risk associated with a business venture: is this the right product of the right quality? will the market prove to be profitable? how should costs and revenues be calculated? can business partners be relied upon to abstain from opportunism? will local government approve of the enterprise, or frustrate it? how secure are profits and assets? These economic and institutional uncertainties have ramifications for the behaviour of actual and potential entrepreneurs.

\subsection{The Relationship between uncertainty and profit}

High uncertainty in the business environment means it would be rational for potential entrepreneurs to expect a large variance in the profits from their business ventures. Consequently, all but those who are the most adventurous, imaginative and riskloving will be eliminated from the subset of those who actually proceed to production. It follows that any action on the part of the potential entrepreneur which results in less uncertainty will increase the expected net returns to a venture and reduce the variance in residual profit, thereby lowering the boundary on entrepreneurship. This being the case, we may predict that the set of actual entrepreneurs will only include those who are best placed to reduce the level of economic and institutional uncertainty. 
But success in production also confers a positive externality on the wider population of potential entrepreneurs in an evolutionary fashion (Nelson, 1996 and 1997). Ceteris paribus, the larger the number of private firms which become established in an emergent market, the better that market functions for all its actual and potential participants, both on the supply side and the demand side. Once again, the boundary on entrepreneurship is lowered. Not only do prices and profits begin to act as reliable signals, but successful entrepreneurship adds to the knowledge base of the economy and offers new models of behaviour to be imitated. Success also exposes new opportunities to supply which, if exploited, generate efficiency gains and raise profit margins. Thus, the market may reach a point where for certain inputs it becomes efficient to switch from the internal hierarchy of the firm to new sources of supply. In other words, as factor and final goods markets become established through successful entrepreneurship, it may be expected that the gains to specialisation associated with an increasing division of labour can be realised. Given the early stage of the reform process, it will be some time before markets are so competitive that profit margins start to be squeezed ${ }^{5}$. Thus, success in entrepreneurship simply adds to the opportunity set faced by the population of would-be entrepreneurs (Nelson, 1996).

\subsection{The relationship between uncertainty and product mix}

In a situation of emergent markets and where there are political as well as economic uncertainties, two special risks attach to the concentration of activity on a single product which call for special kinds of insurance. First, through a combination of poor information, miscalculation, and insufficient expertise, an entrepreneur may find 
themselves operating at the margin where they are at risk of being driven out of the market, for example, where start-up costs have been under-estimated, revenues are less than expected, or the wrong product has been produced. Second, unanticipated changes in the political climate or to the regulatory regime can quickly change business conditions for the worse in a particular market or locality; for example, an entrepreneur may suddenly find their personal and corporate assets at risk of confiscation or actually confiscated. Under these conditions, it becomes rational to consider not only current but future options on business activity by creating and maintaining a portfolio of $>$ real options $=$, that is, a wide-ranging set of production possibilities such that resources can be diverted to additional or alternative activities at minimum cost and at the optimal moment (Jin, 1996; Trigeorgis, 1993).

The attention given by entrepreneurs to current and future production possibilities is exemplified by the perplexity of respondents when asked to specify their core business activity. The notion of $>$ core competence $=$ turned out to be irrelevant to respondents in deciding which activities to engage in. For the most part, a firm is known, not by what it produces, but by who stands behind it, and that individual will seize on any profitable opportunity which presents itself, with scant regard for any core competence the firm may, or may not, have. Case Number 16, for example, began his career in the private sector selling colour television sets and subsequently moved into car and motorcycle sales, real estate, brick production, and the recreational services sector; and Case Number 17 began in the coal and iron industry and expanded into biological engineering and the supply of biological products. 


\subsection{The relationship between uncertainty and investment}

Institutional uncertainty also has implications for the forms taken by investment. Fieldwork reveals that a rational entrepreneur will invest in forms of capital which enhance the ability to move rapidly from one sector to another, or from one locality to another, without the loss of large sunk costs. It might be argued that a necessary requirement for the building up of a core business is >tradeable= input; but as long as a wide range of inputs cannot be safely traded due to the weakness of private property rights and an unstable political climate, a firm needs to exploit any valuable asset it happens to possess. Thus, unlike the modern Western-style firm which tends to concentrate investment on firm-specific or product-specific know-how, entrepreneurs in Shanxi concentrate their investment on transferable assets. And the single most transferable asset which the entrepreneur has is him/herself and their social capital in the form of the ability to mobilise allegiances.

The assets which are embedded in the person of the entrepreneur are secure from confiscation which means they can easily be transferred into alternative incomegenerating activities and from one locality to another. This facet of successful entrepreneurship can explain why most of the individuals encountered in fieldwork were endowed with wide-ranging personal attributes or endowments, such as charm, charisma, and persuasiveness, as well as intelligence, adaptability and imagination; these attributes are immensely valuable in securing cooperation with others. As we shall see below, it is the ability of the entrepreneur to form alliances, and the subsequent rents from cooperation, which are crucial to the establishment and on- 
going profitability of firms. Thus, success in entrepreneurship calls for more than a bright idea, a good product, and the willingness to accept risk. Without heavy investment in the kind of alliances which minimise transaction costs, the future of the firm will always be in serious jeopardy.

\subsection{ALLIANCES.}

It was not until 1994 that banks would give loans to private entrepreneurs and, as we have seen, even now capital markets are poorly developed and supported by an inadequate capital base. Yet obtaining access to financial capital, while clearly important, is not the crucial element in successful entrepreneurship. The potential entrepreneur begins their career in the private sector with a small personal endowment, the single most valuable component of which is his or her social capital $^{6}$. This is because the key to success in entrepreneurship is access to resources. At this stage of the reform process in which information is disaggregated, contractual security is weak, and the assignment of private property rights is incomplete, the ability to gain access to resources translates into the ability of the entrepreneur to locate, and then to affiliate themselves with those with whom there exists the potential to reap mutual benefits. The Western concept of >entrepreneurship $=$ is focused on the ability of the individual to identify profitable opportunities (Kirzner, 1973 and 1985). But, in China, the key factor in successful entrepreneurship is the ability to form an alliance with those economic agents who possess or control the financial assets, physical assets, or specific human capital needed for brokering market entry, that is, for starting production, securing supply, and gaining access to distribution channels (Cheng \& Rosett, 1991; Nee, 1989; 
Boisot, 1995). These alliances render value to the budding entrepreneur, not only by making production possible in the first instance, but by reducing the level of risk and increasing the expected net returns to a venture.

First, the difficulties associated with the dual economy can be overcome by the entrepreneur if entry to the erstwhile socialist sector can be secured. This translates into the need to form an alliance with those politicians or bureaucrats who control entry to the socialist sector. Entry can then be secured through a series of bribes or a share of the profits to a venture, or some other mutually beneficial exchange.

Second, the difficulties associated with weak institutional arrangements can be overcome by forming an alliance with those able to promote and sustain a stable business environment. This can be understood as a form of private collective action. An effective alliance has four transaction cost-saving properties in this respect:

(i) It provides access to insider information which allows the entrepreneur to anticipate changes in the regulatory framework, and to acquire information relating to factor and final goods markets.

(ii) By generating its own influential codes of behaviour, the effective alliance is able to supplement the inadequate legal system with social and political sanctioning thereby providing a higher level of contractual security than would otherwise be the case. 
(iii) The effective alliance provides room for experimentation in two ways: it ensures that an entrepreneur can fail once yet return for a second attempt, and it forms a buffer against failure in the first instance.

(iv) The effective alliance imparts a positive externality: it acts as a form of collective memory, ensuring that a single failure need not be constituted simply as one individual=s loss of investment but as an experience which others can learn from.

Numbers count in the performance of these transaction cost-saving tasks: the greater the number of economic agents who participate in the alliance, the more effective it will be in the dissemination of information, the management of risk, and the monitoring and sanctioning of business practice. With these significant benefits at stake, the fortunes of the entrepreneur are heavily dependent on their ability to form alliances with bureaucrats, political leaders and other significant parties in the business environment.

Third and finally, the ability to form the >right= kind of alliances can mitigate the transaction costs associated with the newness of private enterprise. The problems associated with newness include not only missing institutions, such as the banking services or tort laws which normally support private sector exchanges, but also missing business practices, such as the norms, conventions and routines which determine $>$ how things are done $=$. These practices constitute a form of tacit 
knowledge which is present in the mature economy but missing in the newly reformed China. The effective alliance performs a crucial role in the development of tacit knowledge by creating and promoting a stable set of expectations of $>\operatorname{good}=$ business behaviour. Once again, numbers matter: the greater the number of economic agents who have internalised the same practices of behaviour, the more smoothly and efficiently can business be transacted and the lower the monitoring costs. Conversely, the more heterogeneous the business environment is (that is, the more different practices that co-exist), the higher the transaction costs because each new exchange relation must be negotiated afresh to avoid misunderstandings and ambiguities. Entrepreneurs in China are aware of heterogeneities in their business environment; as several of our respondents indicated, they expect people from other regions to behave differently, and even to speak in dialects they cannot understand. And they are sensitive to the need to create mechanisms to deal with difference, chief of which is the alliance of like-minded individuals who see the value of establishing common practices.

\section{DISCUSSION AND CONCLUSION.}

We have suggested that entrepreneurial success in Shanxi turns crucially on a system of alliances. This system can be understood as a means of creating and mobilising the economic, social and political capital required to lubricate the wheels of private enterprise in an environment characterised by a high level of economic and institutional uncertainty. Within this system, the identities and personal attributes of individuals are key elements, which would explain why we observe a large number of firms with weak organisational identities combined with the high exposure and 
strong personal charisma of the owner. The right kind of alliances help to overcome resource constraints and to minimise transaction costs through the pooling of both tangible and intangible assets, the spreading of risk, the monitoring and enforcement of business deals, and the creation of a stable business environment. Alliances are also valuable because they offer patronage and trust-generating mechanisms, and because they reduce search costs. Thus, alliances function as a repository of knowledge about business opportunities and the location of human resources.

This account of entrepreneurship is distinctive in that it raises the profile of the processes which take place prior to the establishment of the firm and downplays the significance of the production function in its subsequent behaviour. In contrast, the Western-style neoclassical account, which only begins with a production function, and which presupposes that it is economic factors alone which determine the activities of the firm, is inadequate to the task of modelling behaviour. The neoclassicals model has been criticised in the West by institutional economists, and by managerial and behavioural theorists, for its treatment of the firm as a >black box' (Bradach \& Eccles, 1989; Furubotn \& Pejovich, ibid; Granovetter, 1985; Pratten, 1997; Williamson, 1993). The criticism is particularly apt in China where personal identities and the broader architecture of the business environment are crucial factors in the determination of productive activities and the level of profits.

Our account is supported by fieldwork which reveals that entrepreneurs are discriminating in their choice of who to form an alliance with and seek out those who 
offer the highest expected returns. It follows that the expansion path of firms is driven by differential access to alliances; for example, if an entrepreneur has access to alliances which can broker influence in the state sector, he or she is likely to move into productive activities where bureaucratic controls are greatest. In other words, the forms taken by social capital are a driving force in the development of the private sector.

Fieldwork also reveals, in contrast to claims in the literature (Redding, 1996; Fukuyama, ibid), that the family does not play a major and on-going role in the firm. In those cases where a member of the family had given a loan, it was repaid as rapidly as possible, and we came across no instances of a loan being accompanied by legal entitlement to a share in either the risks or the profits associated with the venture. Moreover, a loan did not grant authority in decision-making. These features indicate that neither party regards the loan as an >investment=and, hence, that the family cannot be regarded as a capital-pooling institution.

Given the role of alliances, why is it that entrepreneurship in China has not become prone to the business practices to be found in the countries of the old Soviet Union and, in particular, of Russia, where a single alliance - the Mafia - predominates? Our fieldwork to date has been restricted to one province only and so we can only speculate as to the answer. 
One local explanation may be that Shanxi province was traditionally dominated by state-run heavy industry, notably in coal; this history has bequeathed powerful alliances centred on the Party. Our fieldwork certainly provides evidence of the influential role of Party cadres and other local officials in private enterprise activity, a practice described by Oi (ibid) as >local state corporatism=. We would also suggest that under the conditions we have described in Section 2, the mutual gains to cooperation are highest in the presence of a multiplicity of alliances and where there is an element of competition between alliances. This being the case, individuals and alliances have no incentive to see a single alliance (such as the Mafia) rise to dominance or to limit their allegiance to a single alliance. Certainly, our fieldwork in Shanxi province suggests that no single alliance has the monopoly on all business transactions and that competition between alliances is characterised by a form of $>$ product differentiation=. Ex-army colleagues, for example, specialise in their ability to locate certain kinds of qualified labour and thus provide a pool for engineering and mining skills and expertise with chemicals. We also came across evidence of the part played by alumni clubs in providing access to distribution channels; for example, networks of old classmates were used as reliable contacts by two respondents wanting to market products in distant provinces. Entrepreneurs, for their part, face strong incentives to gain entry to more than one alliance but, because of the positive costs of entry, to be discriminating; they would appear to seek out the combination of alliances which promises the highest returns on membership, rejecting those they have no use for. Of course, it remains to be seen if this system will survive further stages in the transition process. 
In venturing these claims, we do not suggest that cultural difference is the single most important factor in explaining the forms taken by entrepreneurship in different environments ${ }^{7}$. We would argue instead that it is the nature, level and source of uncertainty which determines the particular way in which private markets and their associated institutional practices emerge. Clearly, further comparative work elsewhere in China is needed in order to develop this thesis. But, certainly, our fieldwork so far points to flaws in the neoclassical framework which takes the already-existing firm as the unit of analysis and begins its story there. In our view, a deeper understanding of entrepreneurship may be acquired by treating the firm and its expansion path as an evolutionary process in which the conditions for success and failure are laid down well before an actual firm comes into being.

\section{ACKNOWLEDGEMENT}

The authors gratefully acknowledge the support of the Royal Dutch Academy of Sciences and the Trustfund of Erasmus University.

\section{ENDNOTES}

1. A copy of the interview schedule is available from the authors on request.

2. The seriousness of these problems was openly acknowledged by the senior representative of one of the largest banks in the province who introduced us to many of our respondents. 
3. According to standard economic theory, complete private property rights require a bundle of rights over a good to be defined. Thus, a good is private property if there is: the exclusive right of use, implying the right to exclude others; the exclusive right to receive any income generated by the good; the right to change the form and substance of the good; and the right to transfer ownership. In addition, the transaction costs associated with the enforcement of rights through the courts must be zero or sufficiently low to ensure the pursuit of enforcement is worthwhile. Any divergence from these conditions means that economic agents are unable to realize the full value of their property and, hence, there is a diminishment of the incentive to invest in production.

4. While the $>$ wheeling and dealing $=$ which takes place in spot markets constitutes a form of private enterprise, it may be regarded as conceptually distinct from the more enduring forms of business activity which characterise entrepreneurship and which involve the establishment of a firm and capital accumulation.

5. The profit margins of several respondents were protected by a strong position resulting from a first-mover advantage and/or a total monopoly of the market. When asked whether new entry would place the firm in jeopardy, $16(59 \%)$ respondents answered positively, but only two respondents were actually facing new competition, and one further respondent said he would actually welcome new competition because of the benefits in terms of new technology and ideas. However, we suggest a more significant finding is that new entry is universally seen as a less important factor in success than government policy and local Party attitudes with respect to 
private enterprise. One entrepreneur, for example, pointed out that his firm's control of the market was directly attributable to local government protection. Another respondent said that a barrier to the entry of foreign-owned enterprise into his market (biological engineering products) was created by a central government policy of import-substitution; since this policy was actively supported by the Academy of Sciences, the crucial factor in this firm=s success was perceived to be the maintenance of good relations with the Academy.

6. One respondent made an explicit distinction between Afinancial and social capital

7. The claim that Chinese culture is the driving force behind the emergence of >network capitalism $=$ is discussed in Boisot \& Child (1988 and 1999).

\section{BIBLIOGRAPHY}

Boisot, M., 1995. Information Space: A Framework for Learning in Organizations, Institutions and Culture, London \& New York, Routledge.

Boisot, M. \& Child, J., 1988. The iron law of fiefs: Bureaucratic failure and the problem of governance in Chinese economic reforms, Administrative Science Quarterly, no. 33. 
Bradach, J.L. and Eccles, R. 1989. Price, authority and trust: from ideal types to plural forms, Annual Review of Sociology, no.15

Cheng, L. and Rosett, A. 1991. Contract with a Chinese face: socially embedded factors in the transformation from hierarchy to markets, 1978-1989, Journal of Chinese Law, vol. 5, no. 2

Fukuyama, F. 1995. Trust: the social virtues and the creation of prosperity, New York and London, The Free Press

Furubotn, E. and Pejovich, S. (Eds), 1974. The Economics of Property Rights, Cambridge, MA, Balinger

Gambetta, D. 1993. The Sicilian Mafia: The Business of Protection, Cambridge, MA, Harvard University Press

Granovetter, M. 1985. Economic action and social structure: the problem of embeddedness, American Journal of Sociology, vol. 91, no.3

Herrick B \& Kindleberger C, 1983, Economic Development, McGraw-Hill.

Islam I \& Chowdhury A, 1997, Asia-Pacific Economies, London \& New York: Routledge. 
Jin, C.S. 1996. An evolutionary perspective on diversification and corporate restructuring: entry, exit, and economic performance during 1981-89, Strategic Management Journal, vol. 17

Kirzner, I.M. 1973. Competition and entrepreneurship, Chicago, University of Chicago Press

Kirzner, I.M. 1985. Discovery and the capitalist process, Chicago, University of Chicago Press

Krug, B. 1997, Moving the mountains: transformation as institution building from below, in Backhaus, J. And Krause, G. (Eds), The Political Economy of Transformation: Country Studies, Marburg, Metropolis

Krug, B. and Polos, L. 2000. Entrepreneurs, enterprises, and evolution: the case of China, paper to be presented at the Annual Meeting of the International Society for New Institutional Economics, Tuebingen, September 2000

Lyons, B. and Mehta, J. 1997. Private sector business contracts: the text between the lines, in Deakin, S. and Michie, J., Contracts, Cooperation, and Competition, Oxford, Oxford University Press 
Nee, V. 1989. Peasant entrepreneurship and the politics of regulation in China, in Nee, V. and Stark, D. (Eds), Remaking the Economic Institutions of Capitalism, Stanford, CA, Stanford University Press

Nee, V. 2000. The role of the state in making a market economy, Journal of Institutional and Theoretical Economics, vol. 156, no.1

Nee, V. and Matthews, R. 1996. Market transition and societal transformation in reforming state socialism, Annual Review of Sociology, vol. 22

Nee, V. and Su, S. 1990. Institutional change and economic growth in China, Journal of Asian Studies, vol.49

Nelson, R.R. 1996. The Sources of Economic Growth, Cambridge, MA, Harvard University Press

Nelson, R.R. 1997. How new is new economic growth?, Challenge, vol. 40, no.5

Oi, J.C., 1996. The role of the local state in China=s transitional economy, in Walder A.G., (ed), China=s Transitional Economy, Oxford, Oxford University Press.

Posner, R. 1980. A theory of primitive society, with special reference to law, Journal of Law and Economics, vol. 23, no.1 
Pratten, S. 1997. The nature of transaction costs economics, Journal of Economic Issues, vol. 31, no.3

Redding, S.G. 1996. The distinct nature of Chinese capitalism, The Pacific Review, vol.9, no.3

Rozelle, S. and Li, G. 1998. Village leaders and land-rights formation in China, American Economic Review (papers and proceedings), vol. 82, no.2

Sako, M. 1992. Prices, Quality and Trust, Cambridge, Cambridge University Press

Stigler, J.E. 1989. Markets, market failures, and development, American Economic Review (papers and proceedings), vol.79

Stinchcombe, A.L. 1965. Social structure of organizations, in March, J.G. (Ed), Handbook of Organizations, Chicago, Rand McNally

Trigeorgis, L. 1993. Real options and interactions with financial flexibility, Financial Management (autumn)

Unger J, 1995, 'The decollectivisation of the Chinese countryside: A survey of twenty-eight villages', in Ravenhill J, (ed.), The Political Economy of East Asia: China, Korea and Taiwan Volume II, Aldershot: Edward Elgar. 
Williamson, O. 1993. Calculativeness, trust and economic organization, Journal of Law and Economics, vol. 36, 453-86 


\section{APPENDICES}

TABLE 1: Age and Principal Private Sector Activities of Respondents

\begin{tabular}{|c|c|c|}
\hline $\begin{array}{l}\text { CASE } \\
\text { NO. }\end{array}$ & AGE & PRINCIPAL PRIVATE SECTOR ACTIVITIES \\
\hline 01 & 36 & $\begin{array}{l}\text { wholesale supply of electrical appliances for bakeries, retail sale of } \\
\text { electrical appliances \& furniture }\end{array}$ \\
\hline 02 & 33 & wholesale \& retail supply of cars \& low-quality pick-up trucks \\
\hline 03 & 35 & retail supply of high-quality cars \\
\hline 04 & 38 & $\begin{array}{l}\text { wholesale \& retail sale of truck tyres; in-house production of metal } \\
\text { rims for tyres }\end{array}$ \\
\hline 05 & 30 & production of chemicals \\
\hline 06 & 42 & $\begin{array}{l}\text { production of heating boilers \& air conditioning systems; wholesale } \\
\text { supply of digital televisions }\end{array}$ \\
\hline 07 & 47 & breeding \& cultivation of seed; wholesale \& retail seed merchant \\
\hline 08 & 46 & wholesale supply of food additives \\
\hline 09 & 33 & $\begin{array}{l}\text { design \& supply of >intelligent buildings=; supply of hardware \& } \\
\text { software engineering services; wholesale \& retail supply of office \& } \\
\text { communications equipment }\end{array}$ \\
\hline 10 & 45 & chain of supermarkets; wholesale supplier of specialist noodles \\
\hline 11 & 49 & photographer \\
\hline 12 & 34 & $\begin{array}{l}\text { restaurants; production of industrial coal \& pig iron; trade in coal, } \\
\text { iron \& minerals }\end{array}$ \\
\hline 13 & 48 & manufacture of gold \& silver jewellery, \& tourist souvenirs \\
\hline 14 & 37 & $\begin{array}{l}\text { import \& sale of textiles; retail sale of electronic equipment; car } \\
\text { repair shop; hotel \& restaurant services; advertising services }\end{array}$ \\
\hline 15 & 43 & real estate; construction \\
\hline 16 & 35 & $\begin{array}{l}\text { retail supply of cars \& motor cycles; real estate; brick production; } \\
\text { supply of recreational facilities }\end{array}$ \\
\hline 17 & c.35 & trade in coal \& iron; production of biological engineering products \\
\hline 18 & 40 & educational services (private school for children aged 5+) \\
\hline 19 & 45 & production of aluminium \& electrolysis processors; aluminium \\
\hline
\end{tabular}




\begin{tabular}{|c|c|l|}
\hline & & processing \& plating \\
\hline 20 & 36 & boiler repair shop; design \& production of boilers \\
\hline 21 & 38 & production of preserved fruit \& fruit products, \& soft drinks \\
\hline 22 & 67 & $\begin{array}{l}\text { production of iron moulds, cast-iron clamps, \& zinc-plated fittings \& } \\
\text { machinery }\end{array}$ \\
\hline 23 & 50 & manufacture of pigments \\
\hline 24 & c.50 & manufacture of cast-iron fittings \\
\hline 25 & 49 & manufacture of cast-iron fittings \\
\hline 26 & 37 & coal-mining; iron \& coal traders \\
\hline 27 & 37 & retail sale of sportswear \& sports equipment \\
\hline
\end{tabular}


FOUR ILLUSTRATIVE CASE STUDIES

Note: Respondents' names have been changed to protect their anonymity.

Case study 1: Mr. Chen 
Mr. Chen is $37, \mathrm{He}$ is Chairman of the Board of a large group of companies with 1500 employees. He began his career in the private sector in 1986 with the import and sale of textiles using personal savings of RMB. 5000 (about , 400 at current exchange rates). He formed an unregistered (that is, unofficial) private company in 1989 when he established a small electronic equipment shop, followed by a car repair shop in 1991. Since then, his company has expanded rapidly to embrace: the distribution and sale of car parts and accessories; a car customisation service; the manufacture of car parts; car importation; car rental; hotel \& restaurant services; and advertising services. The major source of capital to fund expansion has been a group of 100 >partners=; but Mr. Chen is Athe big boss $\cong$ (as one of his aides describes him); he has a charismatic personality, takes all major decisions himself, and commands complete loyalty. With his success, the capital offered by banks to

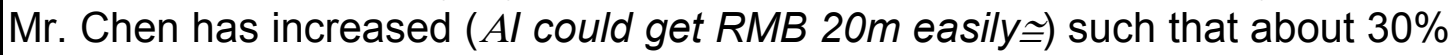
of current assets are in the form of bank debt; but Mr. Chen uses a network of different banks Aso they have to compete for me气.

Mr. Chen has >use rights $=$ of the land on which his buildings are located; these can be purchased for 50 years at a time. Mr. Chen states that the kind of use to which the land is put is vulnerable to political intervention at any time, but he says he is confident that, with his connections and influence, intervention is unlikely.

Mr. Chen's business deals are accompanied by written agreements; but he says that trust and cooperation, supported by his personal reputation, conventions of business practice (which Mr. Chen has played a part in establishing), and the size and robust market position of the company are primary factors in enforcing the good behaviour of business partners.

Mr. Chen is a key figure in the development of the private sector, both in Shanxi Province and beyond. He says he travels frequently to Beijing and the US to maintain his contacts. He is vice-president of his local Association of Industry \& Commerce; he is a Member of a Youth Enterprise Association (with links to local schools and training organizations), the Council of Private Enterprise, the Automobile Engineering Institute, and a Gentlemen=s Club (which meets in his hotel). Mr. Chen describes his relationships with statecontrolled firms, a variety of other firms, and the village community as important to his success; but he describes his relationships with key individuals as essential. Mr. Chen is well connected to the Party: Alf there $=s$ a policy problem, we=ll ask the government for help and urge them to modify

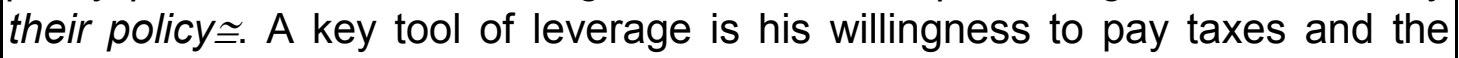
large amount paid. 


\section{Case study 2: Mr. Wang}

Mr. Wang is a graduate of the prestigious Shanghai University. In 1992, he opened a small restaurant with personal savings of RMB. 10,000 (about ,800) enabling him to save a further RMB. 100,000 with which he opened a larger restaurant. Mr. Wang observes that the mid-1990s saw an increase in the level of uncertainty in the sector and so he diverted his resources into the production of industrial coal and pig-iron when he saw an opportunity for entry into this erstwhile state-monopolised sector. His brother helped with a loan. Mr.Wang says that his brother had already formed a private firm offering taxation services, and Ahe transferred his business networks and debts $\cong$ to Mr Wang=s firm. All loans and debts incurred via the brother were rapidly repaid from profits. Mr. Wang says that his major problem with expansion has been gaining access to capital funds at the right time. Mr. Wang now has 250 employees the majority of whom he says he picks up as excess labour from the state-controlled sector. Employees receive generous wages as a reward to good performance, but also in bad times Ato encourage them气. Mr. Wang says that he particularly values their willingness to alert him to investment opportunities.

Mr. Wang faces serious problems in obtaining enough land to meet his expansion plans, and insecurity in its use as a result of poorly defined land rights.

Mr. Wang's business deals are supported by verbal agreements. He observes that monitoring is easy because most products are standardised, but that mutual trust, cooperation, and flexibility, together with his personal reputation and honesty, are vital to the success of his ventures.

Mr. Wang says that his relationships with firms and individuals in the state sector are vital to his success since he is dependent on them for access to key resources and for market entry; for their part, the state-owned enterprises must barter for Mr Wang's products due to lack of cash. He says he is also dependent on good relations with township governments, village heads, and villagers in the areas where his factories are located since otherwise Athey will cause trouble $\cong$ over land use and transport issues. Mr Wang says his relationship with his brother was essential when he first began as an entrepreneur because he was deemed to be an outsider as a result of his period in Shanghai; this connection is less important Anow that I have established my own networks $\cong$. He says that township and village enterprises are important customers; these are linked into a network and, since it is the network with which he conducts business, his personal reputation and $>$ connectedness $=$ within this network are vital to the success of his transactions. 
Case study 3: Mr. Xiang.

Mr. Xiang is 67. His firm was originally the state-owned enterprise which employed him for most of his life and which was founded in 1957 with 6 employees. Mr. Xiang recounts how ten months=ago, the firm was bought out by its 45 managers, each of whom had a small amount of personal savings; but Mr Xiang is the largest shareholder (with $60 \%$ of shares) and the principal decision-maker. The firm now has more than 1000 employees, most of whom had been discarded by state-owned factories in the locality. The firm produces iron moulds, cast-iron clamps, and zinc-plated fittings and machinery, which are supplied to customers throughout China and in Europe. It has a robust market position which Mr. Xiang claims is due to his willingness to introduce Western technology and his loyalty to the Party.

Agreements to trade are supported by written contracts, and regular inspections of Mr. Xiang's premises. But he says that since many of his customers are >old friends=, mutual trust, cooperation and flexibility play a major role in the success of the firm.

Mr. Xiang clearly builds on his long-established connections with the State and within state-owned enterprises to maintain the valuable customer and supplier base he inherited and has since expanded. He is a member of the Committee for Power Line Materials of the Ministry of Power, and has been appointed the sole manufacturer of power armour clamps for the Ministry. Mr. Xiang says he drew on personal connections in order to secure the private water and power supplies which are vital to his rurally-located operation. Good relations with the village authorities recently enabled him to build a road connecting to the main highway. Mr. Xiang observes that human resources are most important to the success of his business and that he has good relations with the Workers Union, as well as the Consumers Association and his Trade Association. Political influence at the local level is also important to Mr Xiang's enterprise; he is a loyal Party member and proud of the large pictures of Marx, Lenin, Engels, and Mao displayed in his office.

\section{Case study 4: Mr. Zhu.}

- Mr. Zhu is 36. He began his career in the private sector 15 years' ago when he set up a boiler repair shop with 7 employees. He says that old-style boilers were noisy and his innovation was to make them work quietly. Mr. Zhu says he has never turned to the bank for loans but uses the cash paid in deposits on boilers as capital for expansion. He states that his firm is immune from political events "because I have influence" and that his dominant position in the market is protected because "I am too big". Mr. Zhu describes himself as "the Boiler King". He portrays his expansion to an enterprise with nine branches in different provinces, 1672 employees, and a turnover of RMB300 million, as seamless. In fact, Mr.Zhu had forgotten that he had been interviewed by one of the authors two years' previously, shortly after he had been declared bankrupt following entry into the supermarket sector and investment in a shopping mall. This event was widely known since it was reported in the press. Senior Party cadres had introduced us to Mr. Zhu as a 
"model entrepreneur". Mr. Zhu and the Party cadres only reluctantly confirmed this earlier business failure, pointing both to its insignificance and to "the difficult trading conditions" prevailing at the time. Soon after this admission, the authors politely brought the interview to an end. Responses to questions were becoming incoherent, perhaps due to the quantity of alcohol being imbibed by Mr. Zhu and the Party cadres. Drinking was accompanied by toasts to the Party, and to China as represented by the boiler industry. The authors concluded that the relationship between Mr. Zhu and the Party has been of major significance in Mr. Zhu's economic activities, although the precise nature of the relationship remains unclear. 


\title{
Publications in the ERIM Report Series Research* in Management
}

\author{
ERIM Research Program: "Organizing for Performance"
}

\section{1}

Employee Perception on Commitment Oriented Work Systems: Effects onTrust and Perceived Job Security Paul Boselie, Martijn Hesselink, Jaap Paauwe \& Ton van der Wiele

ERS-2001-02-ORG

The Emergence of a Private Business Sector in China: The Case of Zhejiang

Barbara Krug \& Hans Hendrischke

ERS-2001-03-ORG

Contingent Employment in the Netherlands

Ferrie Pot, Bas Koene \& Jaap Paauwe

ERS-2001-04-ORG

Under Construction. (Idendities, Communities and Visual Overkill)

Slawomir Magala

ERS-2001-17-ORG

The Dutch Banking Chipcard Game: Understanding a Battle between Two Standards

Henk J. de Vries \& George W.J. Hendrikse

ERS-2001-18-ORG

Social Structures for Learning

Irma Bogenrieder \& Bart Nooteboom

ERS-2001-23-ORG

Empirical Evidence for the relation between customer satisfaction and business performance? Ton van der Wiele, Paul Boselie \& Martijn Hesselink

ERS-2001-32-ORG

On the emergence of growers' associations: self-selection versus market power

G.W.J. Hendrikse \& W.J.J. Bijman

ERS-2001-34-ORG

Employee perceptions of HRM and TQM and the effects on satisfaction and intention to leave Paul Boselie \& Ton van der Wiele

ERS-2001-42-ORG

Project Contract Management and a Theory of Organization

J. Rodney Turner \& Stephen J. Simister

ERS-2001-43-ORG

The Geography of International Strategy: A multi-level framework

Douglas van den Berghe

ERS-2001-51-ORG

* A complete overview of the ERIM Report Series Research in Management:

http://www.ers.erim.eur.nl

ERIM Research Programs:

LIS Business Processes, Logistics and Information Systems

ORG Organizing for Performance

MKT Marketing

F\&A Finance and Accounting

STR Strategy and Entrepreneurship 
"The E-Business Research Network". Summary of the results of the Dutch pilot survey Ton van der Wiele, Roger Williams, Jos van Iwaarden, Melanie Wilson \& Barrie Dale ERS-2001-59-ORG

Cold Wars and Hot Issues. (Management of Responsibilities)

Dr Slawomir Magala

ERS-2001-64-ORG

Macro Intentions, Micro Realities: A two-level strategic approach to the single European market Alan Muller \& Rob van Tulder

ERS-2001-70-ORG

Learning and Governance in Inter-Firm Relations

Bart Nooteboom

ERS-2001-71-ORG

Research in the Management of Learning, Change and Relations: a European Perspective

Bart Nooteboom

ERS-2001-72-ORG

The Causality of Supply Relationships: a Comparison between the US, Japan and Europe

Gjalt de Jong \& Bart Nooteboom

ERS-2001-73-ORG

Problems and Solutions in Knowledge Transfer

Bart Nooteboom

ERS-2001-74-ORG

The practice of investment appraisal: An empirical enquiry?

Mehari Mekonnen Akala \& Rodney Turner

ERS-2001-77-ORG

Investment Appraisal Process: A Case of Chemical Companies

Mehari Mekonnen Akala \& Rodney Turner

ERS-2001-78-ORG

China Incorporated: Property Rights, Privatisation, and the Emergence of a Private Business Sector in China Barbara Krug \& Hans Hendrischke

ERS-2001-81-ORG

Kultur und wirtschaftliche Entwicklung in China

Barbara Krug

ERS-2001-82-ORG

The Economics of corruption and cronyism - an institutional approach

Barbara Krug \& Hans Hendrischke

ERS-2001-83-ORG

Combining Commerce and Culture: Establishing Business Relations in China

Barbara Krug \& Frank Belschak

ERS-2001-84-ORG

Entrepreneurship by Alliance

Barbara Krug \& Judith Metha

ERS-2001-85-ORG 
Critical Complexities, from marginal paradigms to learning networks

Slawomir Magala

ERS-2000-02-ORG

Marketing Cooperatives and Financial Structure: a Transaction Costs Economics Analysis

George W.J. Hendrikse \& Cees P. Veerman

ERS-2000-09-ORG

A Marketing Co-operative as a System of Attributes: A case study of VTN/The Greenery International BV, Jos Bijman, George Hendrikse \& Cees Veerman ERS-2000-10-ORG

Marketing Co-operatives: An Incomplete Contracting Perspective

George W.J. Hendrikse \& Cees P. Veerman

ERS-2000-13- ORG

Ownership Structure in Agrifood Chains: The Marketing Cooperative

George W.J. Hendrikse \& W.J.J. (Jos) Bijman

ERS-2000-15-ORG

Organizational Change and Vested Interests

George W.J. Hendrikse

ERS-2000-17-ORG

Is Polder-Type Governance Good for You? Laissez-Faire Intervention, Wage Restraint, And Dutch Steel Hans Schenk

ERS-2000-28-ORG

Foundations of a Theory of Social Forms

László Pólos, Michael T. Hannan \& Glenn R. Carroll

ERS-2000-29-ORG

Reasoning with partial Knowledge

László Pólos \& Michael T. Hannan

ERS-2000-30-ORG

The Strawberry Growth Underneath the Nettle: The Emergence of Entrepreneurs in China

Barbara Krug \& Lászlo Pólós

ERS-2000-34-ORG

Trading Virtual Legacies

Slawomir Magala

ERS-2000-36-ORG

The Interdependence between Political and Economic Entrepeneurship

Barbara Krug

ERS-2000-43-ORG

Ties that bind: The Emergence of Entrepreneurs in China

Barbara Krug

ERS-2000-44-ORG

Human Resource Management and Performance: Lessons from the Netherlands

Paul Boselie, Jaap Paauwe \& Paul Jansen

ERS-2000-46-ORG 
Possible futures for the HR function in different market Roger Williams, Jaap Paauwe \& Anne Keegan

ERS-2000-54-ORG

Quantity versus Quality in Project Based Learning Practices Anne Keegan \& J. Rodney Turner

ERS-2000-55-ORG

The Management of Innovation in Project Based Firms

Anne Keegan and J. Rodney Turner

ERS-2000-57-ORG

Learning by Experience in the Project-Based Organization J. Rodney Turner, Anne Keegan \& Lynn Crawford ERS-2000-58-ORG 